\title{
Pembinaan Akademik untuk Meningkatkan Kemampuan Guru SMA Sumatera 40 Bandung Membuat Perencanaan Pembelajaran
}

\author{
Ida Suciati Mandirisari \\ Pengawas SMA Kota Bandung, Cabang Dinas Wilayah VII, \\ Dinas Pendidikan Propinsi Jawa Barat \\ Email: idasucimandirisari@yahoo.co.id
}

\begin{abstract}
Abstrak.
Guru harus memfasilitasi dan mengambangkan kemampuan memecahkan masalah sejak dini pada diri siswa SMA, dengan memasukan kemampuan tersebut pada perencanaan pembelajaran yang dibuatnya. Penelitian ini bertujuan untuk meningkatkan keterampilan berpikir tingkat tinggi pada siswa. Metode penelitian yang digunakan adalah penelitian tindakan sekolah, yaitu melaksanakan pembinaan bagi sekelompok guru di suatu sekolah, melalui beberapa siklus, mengunakan sistem spiral refleksi model Kemmis dan Mc Taggart yang dimodifikasi. Strategi/metode kerja/ teknik pembinaan yang digunakan dari siklus I sampai siklus II menggunakan model supervisi klinis melalui observasi-refleksirekomendasi, studi dokumentasi angket, FGD, dan presentasi produk RPP. Hasil penelitian menunjukkan bahwa setelah dilaksanakan supervisi model supervisi klinis, kemampuan guru dalam membuat perencanan pembelajaran berbasis pemecahan masalah, sudah menunjukkan adanya peningkatan, dari siklus I ke Siklus II. Siklus II mengakhiri pembinaan, dengan indikator skor guru minimal 80.00 sudah diatas $85 \%$, yaitu sebesar $100 \%$.
\end{abstract}

Kata Kunci: Pembinaan akademik, kemampuan guru, perencanaan pembelajaran

\section{PENDAhULUAN}

Proses pembelajaran di sekolah menengah harus mengembangkan serta menanamkan pembelajaran kecakapan hidup abad 21 yaitu: (1) kemampuan memecahkan masalah dan kemampuan berpikir kritis, (2) kemampuan berkolaborasi, (3) kemampuan berkomunikasi, serta (3) kreatif dan berinovasi, ke empat kecakapan hidup tersebut dikenal dengan istilah 4C, (5) kemampuan literasi, dan (6) mempersiapkan karier dan kecakapan hidup (Forgaty, 1997; 
Salpeter, 2001; Tan, 2003; Lazear, 2004; Permendikbud No. 20 tahun 2016 dan Permendikbud No 21 tahun 2016). Oleh karena itu, guru harus memfasilitasi dan mengambangkan ke enam kemampuan tersebut sejak dini pada diri siswa SMA, dengan memasukan kemampuan tersebut pada Rencana Pelaksanaan Pembelajaran (RPP).

Kemampuan memecahkan masalah sebagai bagian dari kemampuan 4C, sangat penting dikuasai siswa untuk mempersiapkan diri menghadapi berbagai permasalahan dan menentukan solusinya serta mendorong terbentuknya keterampilan berpikir tingkat tinggi (Forgaty, 1997; Savoi, 1994; Tan, 2003; Wood, 2005, Permendikbud No. 20, 21 dan No. 22 Tahun 2016). Namun kenyataannya di lapangan hasil observasi, studi dokumentasi RPP dan angket pada guru di sekolah binaan, menunjukkan: (1) sebagian guru belum menggunakan model berbasis pemecahan masalah dalam RPPnya, padahal Kompetensi Dasar (KD) yang dapat menggunakan model berbasis pemecahan masalah relatif cukup banyak; (2) sebagian guru yang menuliskan model berbasis pemecahan masalah pada RPPnya, tapi tidak menuliskan sintaks model tersebut pada langkah-langkah pembelajaran; (3) sebagian guru yang memilih model berbasis pemecahan masalah tetapi KD yang dipilih tidak sesuai jika menggunakan model berbasis pemecahan masalah. Oleh karena itu, perlu adanya supervisi akademik khususnya pembinaan dengan menggunakan metode workshop yang dilakukan oleh pengawas, supaya kompetensi dan profesionalisme guru dapat berkembang, khususnya kompetensi pedogogik guru dalam menerapkan berbagai pendekatan, strategi, metode dan model pembelajaran yang mendidik secara kreatif dan variatif dalam mata pelajaran yang diampu (Permendiknas No 16 tahun 2007), salah satunya adalah model Problem Based Learning (PBL).

Tujuan dari penerapan pembelajaran berbasis pemecahan masalah adalah mendorong siswa, untuk terlibat aktif dalam membangun pengetahuan, sikap, dan prilaku melalui kegiatan memecahkan suatu masalah. Melalui kegiatan pemecahan masalah terhadap permasalahan yang ada, maka pada akhirnya siswa terbiasa memecahkan masalah yang dihadapi dalam kehidupan sehari-hari, menentukan solusinya serta mendorong terbentuknya keterampilan berpikir tingkat tinggi, sehingga siswa memiliki tanggung jawab atas dirinya sendiri dan kepada masyarakat (Carson, 2007; Dogru, 2008; Allen, 1996; Azer, 2013; Barrett, 2005; Duch, 2001; Savoi, 1994). Berdasarkan penjelasan tersebut peneliti telah melaksanakan penelitian tindakan sekolah untuk meningkatkan kemampuan guru di SMA Sumatera 40 Bandung dalam membuat RPP berbasis pemecahan masalah yang merujuk pada kurikulum 2013 revisi, melalui supervisi akademik menggunakan model supervisi klinis

\section{II.METODOLOGI PENELITIAN}

Metode penelitian yang digunakan adalah Penelitian Tindakan Sekolah yaitu melaksanakan pembinaan bagi sekelompok guru di suatu sekolah, melalui beberapa siklus, mengunakan sistem spiral refleksi model Kemmis dan Mc 
Taggart yang dimodifikasi (Sukidin dkk, 2002; Sumarno, 2005; \& Wiriaatmadja, 1999), dengan tahapan mulai dari merencanakan pembinaan setiap siklus, pelaksanan pembinaan setiap siklus, observasi pelaksanaan dan refleksi pembinaan setiap siklus, yang dilakukan dari siklus I sampai siklus II dan seterusnya sampai diperoleh rekomendasi kemampuan guru pada siklus terakhir tuntas. Indikator ketuntasan apabila telah mencapai $85 \%$ subjek daya serapnya $\geq$ $70 \%$ (Depdikbud RI, 1994, dalam Sudjana, 2001 dan Arikunto, 2003).

\section{Strategi/Metode/Teknik Pembinaan}

Strategi/metode kerja/teknik pembinaan yang digunakan dari siklus I sampai siklus II menggunakan model supervisi klinis melalui observasi-refleksirekomendasi, studi dokumentasi angket, FGD, dan presentasi produk RPP

\section{Setting/Lokasi/Subyek Penelitian}

\section{Setting Penelitian}

Secara garus besar, prosedur siklus dilakukan melalui kegiatan perencanaan (plan), siklus (act), observasi (observe) dan refleksi (reflect).

Adapun prosedur pengembangan model siklus yang dilaksanakan dalam penelitian ini dapat dilihat pada Bagan 1 di bawah ini :

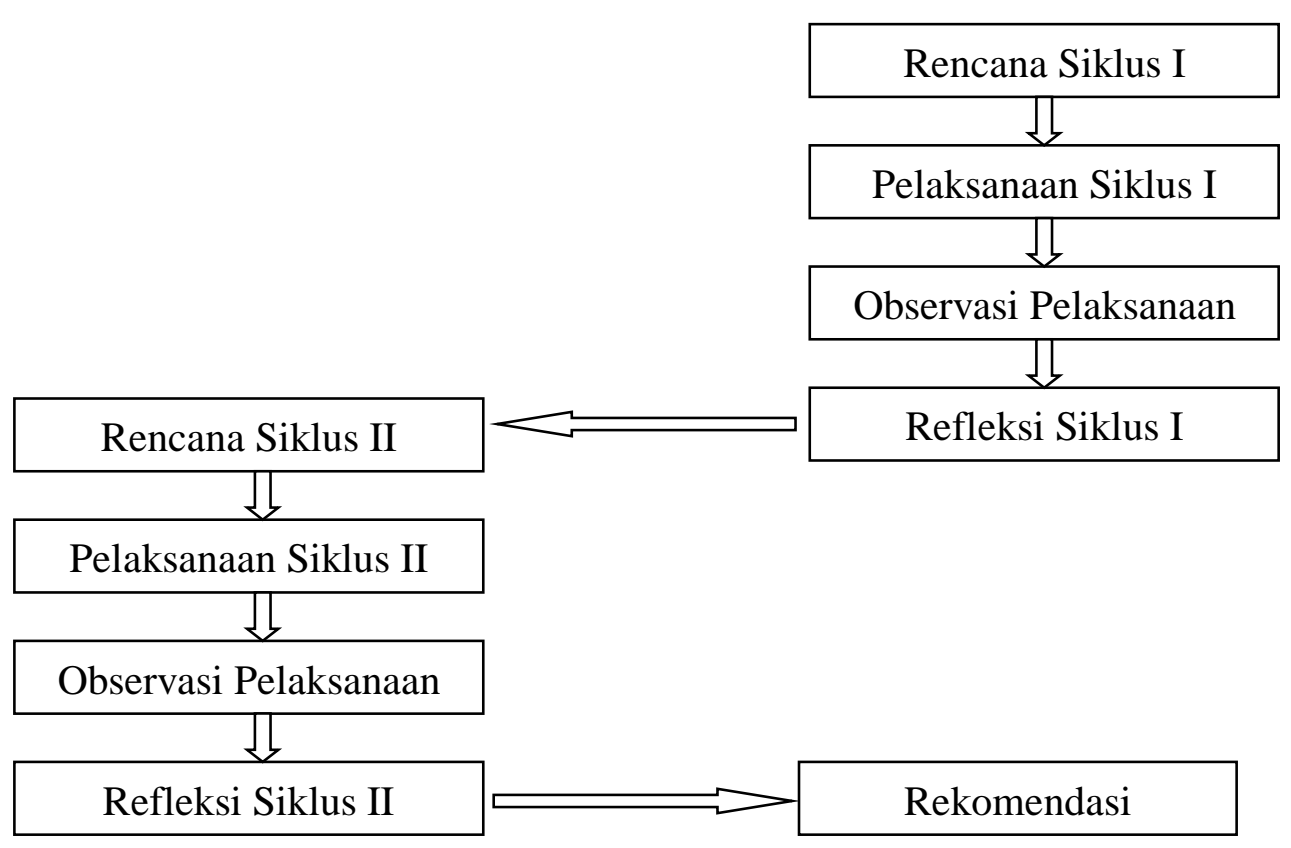

Bagan 1. Prosedur Pengembangan Model Siklus (Kemmis dalam Hopkin, 1993, dikutip Sukidin, 2002).

Prosedur penelitian tersebut dilaksanakan dalam lima tahapan yaitu : 
1) Rencana tindakan pembinaan, yaitu merumuskan rencana pembinaan setiap kali akan melaksanakan pembinaan serta fokus yang akan diamati selama pelaksanaan pembinaan

2) Penilaian terhadap keterampilan guru dalam membuat materi pelajaran dalam bentuk power point

3) Observasi pembinaan guru, adalah proses mendokumentasikan pengaruh, kendala, tindakan pembinaan, serta persoalan yang mungkin ada, pada saat pembinaan berlangsung. Observasi dibantu oleh observer (rekan kepala sekolah) sehingga observasi akan menjadi efektif dan efisien, observer mengobservasi peneliti dan guru selama pelaksanaan pembinaan, penelitipun mengamati proses serta kegiatan yang dilaksanakan oleh guru, serta mencatat kendala-kendala yang dihadapi guru. Hasil observasi itu mendasari refleksi untuk siklus yang telah dilakukan dan dijadikan pertimbangan untuk menyusun rencana siklus selajutnya

4) Refleksi, yaitu menjelaskan setiap efek-efeknya dan kegagalan pelaksanaan. Rekomendasi ini hasil kolaborasi antara guru, peneliti dan observer serta dengan kepala sekolah, untuk mendiskusikan kelebihan dan kekurangan serta pengaruhnya dalam kegiatan pembinaan pada setiap siklus selama penelitian dilaksanakan Diskusi balikan, dilakukan antara guru, peneliti, observer serta dengan kepala sekolah, terhadap hasil observasi. Hasil diskusi balikan merupakan refleksi dari hasil observasi yang kemudian di interpretasi dan dijadikan rencana untuk memperbaiki kekurangan-kekurangan yang ada pada siklus yang telah dilaksanakan, untuk diterapkan pada siklus selanjutnya

\section{Subyek dan Waktu Penelitian}

Subyek penelitian dalam penelitian ini adalah guru di SMA Sumatera 40 Bandung, jumlah guru yang diteliti sebanyak 18 guru. Penelitian dilaksanakan dari tanggal 22 Juli - 26 Agustus 2019

\section{Instrumen Penelitian}

Untuk memperoleh data yang diharapkan, maka dalam penelitian ini digunakan instrumen sebagai berikut: 1) rencana pelaksanaan pembinaan, 2) pedoman observasi aktivitas guru, 3) daftar chek aktivitas guru, 4) format observasi aktivitas guru, 5) format observasi pembinaan, dan 6) format diskusi balikan

\section{Prosedur Pengolahan dan Analisis Data}

Data yang telah diperoleh pada setiap tahapan siklus diolah dan dinalisis melalui tahap-tahap sebagai berikut

\section{1) Kategori Data}

Kategori Data dalam penelitian ini adalah : tingkat penguasaan dan keterampilan guru dalam perencanaan pembelajaran berbasis pemecahan masalah dalam melaksanakan pembelajaran 


\section{2) Interpretasi Data}

Indikator keberhasilan penelitian siklus ini adalah ketuntasan pembinaan dan daya serap guru. Pembinaan telah tuntas bila telah tercapai $85 \%$ guru mencapai daya serap $\geq 70 \%$ (Depdikbud RI, 1994 dalam Sudjana, 2001). Untuk menghitung persentase diatas dapat menggunakan rumus sebagai berikut :

$\mathrm{DSK}=\left(\sum\right.$ guru yang memperoleh tingkat penguasaan $\left.\geq 70 \%\right) \times 100 \%$

$$
\text { Jumlah guru }
$$

\section{3) Validitas data}

Agar data yang diperoleh sahih dan andal, maka dilakukan teknik triangulasi, yaitu dengan melakukan beberapa siklus antara lain:

- Melakukan pengecekan ulang dari data yang telah terkumpul untuk kelengkapannya.

- Melakukan pengolahan dan analisis ulang dari data yang terkumpul.

- Membuat perangkat test

- Pembuatan lembar observasi untuk guru dan instrumen lainnya.

4) Pelaksanaan Siklus

- Menerapkan pembinaan

- Mengobservasi aktifitas guru dan peneliti selama pembinaan belangsung

- Melaksanakan refleksi terhadap guru dan peneliti selama pembinaan

- Bersama observer (rekan kepala sekolah) memberikan rekomendasi dari hasil pembinaan setiap siklus

\section{5) Evaluasi}

- Observasi keaktifan guru dan peneliti selama pembinaan

- Observasi pelaksanaan pembinaan

- Diskusi balikan antara guru dengan peneliti, observer dan kepala sekolah setiap menyelesaikan proses pembinaan

\section{6) Analisis dan Refleksi}

Langkah-langkah dalam refleksi siklus terdiri atas :

- Mengidentifikasi permasalahan-permasalahan yang sudah dan belum terpecahkan serta yang muncul selama siklus berlangsung.

- Menganalisis dan merinci pembinaan yang telah dilakukan dan efektifitas pembinaan berdasarkan kendala-kendala yang dihadapi peneliti dan guru.

- Menentukan siklus selanjutnya berdarkan hasil analisis refleksi yang dilakukan secara kolaborasi atara guru, peneliti, observer serta kepala sekolah

\section{HASIL PENELITIAN DAN PEMBAHASAN}

\section{Hasil Penelitian Aktivitas Guru pada Siklus 1}


Aktivitas guru pada siklus I, dapat dilihat pada Tabel 4.1:

Tabel 4.1

Aktivitas Guru Pada Siklus 1

\begin{tabular}{|c|l|c|c|}
\hline No & \multicolumn{1}{|c|}{ Kriteria yang diamati } & Jumlah Guru & \% \\
\hline 1 & Terampil membuat RPP berbasis pemecahan masalah & 12 & 66.67 \\
\hline 2 & $\begin{array}{l}\text { Terampil membuat penilaian berbasis pemecahan } \\
\text { masalah }\end{array}$ & 12 & 66.67 \\
\hline 3 & $\begin{array}{l}\text { Terampil membuat angket respon siswa terhadap } \\
\text { penggunaan PBL }\end{array}$ & 13 & 72.22 \\
\hline 4 & $\begin{array}{l}\text { Terampil membuat pedoman observasi aktivitas siswa } \\
\text { berbasis pemecahan masalah }\end{array}$ & 13 & 77.78 \\
\hline 5 & $\begin{array}{l}\text { Terampil membuat daftar check berbasis pemecahan } \\
\text { masalah }\end{array}$ & $\begin{array}{l}\text { Terampil membuat format observasi aktivitas siswa } \\
\text { berbasis pemecahan masalah }\end{array}$ \\
\hline 6
\end{tabular}

Tabel 4.1 diatas, menunjukkan bahwa guru yang melakukan aktivitas membuat RPP berbasis pemecahan masalahdengan benar, berjumlah 12 orang $(66.67 \%)$, terampil membuat penilaian berbasis pemecahan masalah sebanyak 12 orang $(66.67 \%)$, terampil membuat angket respon siswa sebanyak 13 orang $(72.22 \%)$, terampil membuat pedoman observasi aktivitas siswa berbasis pemecahan masalah sebanyak 13 orang (72.22\%), terampil membuat daftar check berbasis pemecahan masalah sebanyak 14 orang $(77.78 \%$ ), dan terampil membuat format observasi aktivitas siswa berbasis pemecahan masalah sebanyak 14 orang $(77.78 \%)$.

Tabel 4.1 diatas menggambarkan bahwa kemampuan guru dalam dalam membuat RPP berbasis pemecahan masalah relatif perlu ditingkatkan. Hal ini disebabkan karena sebagian besar guru selalu membuat RPP berbasis metode ceramah, sehingga untuk memulai membuat RPP menggunakan model pembelajaran lain yang inovatif salah satunya PBL, relatif belum terbiasa.Selain itu pada saat membuat instrument pembelajaran lain berbasis pemecahan masalah, mulai dari membuat angket respon siswa, membuat pedoman observasi aktivitas siswa, membuat daftar check, dan membuat format observasi aktivitas siswa guru belum terbiasa

Evaluasi Kemampuan Guru dalam membuat RPP berbasis pemecahan masalah yang sesuai dengan tuntutan Permendikbud No 22 Tahun 2016 tentang Standar Proses pada Siklus I

Kemampuan guru dalam membuat membuat RPP berbasis pemecahan masalah yang sesuai dengan tuntutan Permendikbud No 22 Tahun 2016, tentang Standar Proses pada siklus I, dapat dilihat pada Tabel 4.2

Tabel 4.2

Jumlah Komponen RPP Berbasis pemecahan masalah yang Dipenuhi oleh

Guru 
(dari Total 20 Komponen RPP yangSesuai dengan Tuntutan Permendikbud No 22 Tahun 2016)pada Siklus I

\begin{tabular}{|c|c|c|c|}
\hline No & Kode Guru & $\begin{array}{c}\text { Jumlah komponen RPP berbasis } \\
\text { pemecahan masalah yang Dipenuhi oleh } \\
\text { Guru (dari total 20 komponen RPP) }\end{array}$ & $\%$ \\
\hline 1 & AA & 13 & 65,00 \\
\hline 2 & AB & 15 & 75,00 \\
\hline 3 & AC & 11 & 55,00 \\
\hline 4 & AD & 12 & 60,00 \\
\hline 5 & AE & 16 & 80,00 \\
\hline 6 & AF & 15 & 75,00 \\
\hline 7 & AG & 14 & 70,00 \\
\hline 8 & AH & 11 & 55,00 \\
\hline 9 & AI & 14 & 70,00 \\
\hline 10 & AJ & 15 & 75,00 \\
\hline 11 & AK & 13 & 65,00 \\
\hline 12 & AL & 16 & 80,00 \\
\hline 13 & AM & 14 & 70,00 \\
\hline 14 & AN & 15 & 75,00 \\
\hline 15 & AO & 14 & 70,00 \\
\hline 16 & AP & 13 & 65,00 \\
\hline 17 & AQ & 16 & 80,00 \\
\hline 18 & AR & 13 & 65,00 \\
\hline \multicolumn{2}{|r|}{ Rata-rata } & 14 & 69,44 \\
\hline
\end{tabular}

Uraian 20 komponen RPP yang Sesuai dengan Tuntutan Permendikbud No 22 Tahun 2016 sebagai berikut:

\begin{tabular}{|c|c|c|c|}
\hline No & Komponen RPP & No & Komponen RPP \\
\hline 1 & $\begin{array}{l}\text { Mencantumkan identitas } \\
\text { sekolah/nama satuan pendidikan }\end{array}$ & 11 & Materi pelajaran memuat prinsip relevan dengan indikator \\
\hline 2 & $\begin{array}{l}\text { Mencantumkan identitas mata } \\
\text { pelajaran }\end{array}$ & 12 & Materi pelajaran memuat prosedur relevan dengan indicator \\
\hline 3 & $\begin{array}{l}\text { Mencantumkan identitas } \\
\text { kelas/semester }\end{array}$ & 13 & $\begin{array}{l}\text { Metode pembelajaran sesuai dengan tuntutan KD/ } \\
\text { indikator/tujuan }\end{array}$ \\
\hline 4 & $\begin{array}{l}\text { Mencantumkan materi pokok } \\
\text { dan sub materi pokok }\end{array}$ & 14 & Metode pembelajaran sesuai dengan karakteristik siswa \\
\hline 5 & $\begin{array}{l}\text { Mencantumkan alokasi waktu } \\
\text { (termasuk jumlah pertemuan) }\end{array}$ & 15 & $\begin{array}{l}\text { Media pembelajaran sesuai dengan tuntutan KD/ } \\
\text { indikator/tujuan }\end{array}$ \\
\hline 6 & $\begin{array}{l}\text { Mencantumkan KD yang sesuai } \\
\text { untuk model berbasis } \\
\text { pemecahan masalah }\end{array}$ & 16 & Sumber belajar sesuai dengan tuntutan KD/ indikator/tujuan \\
\hline 7 & Mencantumkan Indikator & 17 & $\begin{array}{l}\text { Langkah-langkah pembelajaran melalui tahapan } \\
\text { pendahuluan, kegiatan inti, dan penutup }\end{array}$ \\
\hline 8 & $\begin{array}{l}\text { Rumusan tujuan pembelajaran } \\
\text { berdasarkan KD/indikator }\end{array}$ & 18 & $\begin{array}{l}\text { Langkah-langkah pembelajaran memuat sintaks/ langkah- } \\
\text { langkah model berbasis pemecahan masalah (orientasi siswa } \\
\text { kepada masalah, mengorganisasi siswa untuk belajar, } \\
\text { membimbing penyelidikan individual dan kelompok, } \\
\text { mengembangkan dan menyajikan hasil karya, dan } \\
\text { menganalisis dan mengevaluasi proses pemecahan masalah; } \\
\text { Sumber: Arends, 2008) }\end{array}$ \\
\hline
\end{tabular}




\begin{tabular}{|c|l|c|l|}
\hline 9 & $\begin{array}{l}\text { Materi pelajaran memuat fakta } \\
\text { relevan dengan indikator }\end{array}$ & 19 & $\begin{array}{l}\text { Langkah-langkah pembelajaran mengembangkan ranah } \\
\text { sikap, pengetahuan, dan keterampilan }\end{array}$ \\
\hline 10 & $\begin{array}{l}\text { Materi pelajaran memuat konsep } \\
\text { relevan dengan indikator }\end{array}$ & 20 & Penilaian sesuai dengan tuntutan KD/ indikator/tujuan \\
\hline
\end{tabular}

Data pada Tabel 4.2 menunjukkan bahwa jumlah komponen terkecil RPP berbasis pemecahan masalah yang dipenuhi guru, dari total 20 komponen RPP yang sesuai dengan tuntutan Permendikbud No 22 Tahun 2016,pada Siklus I sebanyak 11 komponen $(55.00 \%)$ dilakukan oleh dua orang guru $(11.11 \%)$. Sedangkan jumlah komponen terbanyak yang dipenuhi guru sebanyak 16 komponen $(80.00 \%)$ dilakukan oleh tiga orang guru (16.67\%).Rata-rata jumlah komponen yang dipenuhi guru sebanyak 14 komponen $(70.00 \%)$ dengan daya serap klasikal sebesar $61.11 \%$.

\section{Refleksi dan Revisi Siklus 1}

Pembinaan pada siklus I, menunjukkan bahwa pada siklus pertama menunjukkan kelebihan dan kekurangan. Kelebihannya yaitu, peneliti mulai menerapkan langkah-langkah pembinaan sesuai dengan rencana pembinaan siklus I yang telah dibuat peneliti, kemudian guru sangat antusias untuk meningkatkan kemampuannya dalam membuatRPP berbasis pemecahan masalah. Kekurangan yang ada pada pelaksanaan siklus 1 diantaranya :

- Pemberian motivasi dan apresiasi pada saat akan melakukan pembinaan oleh peneliti masih harus ditingkatkan

- Pada saat melaksanakan pembinaan, peneliti masih dominan di barisan paling depan, serta kurang intensif melakukan pembinaan yang komunikatif dengan guru, terutama pada saat guru mengalami kesulitan dalam membuat RPP

- Peneliti kurang mengeksplore potensi guru untuk mengembangkan kemampuannya dalam membuat RPP berbasis pemecahan masalah, dengan menugaskan guru mencari di berbagai sumber yang relevan.

Berdasarkan kekurangan yang ada pada pelaksanaan siklus 1, maka pelaksanaan pembinaan pada siklus II, perlu memperhatikan perbaikanperbaikan seperti di bawah ini :

- Peneliti harus memberikan motivasi dan apresiasi pada saat akan melakukan pembinaan

- Peneliti pada saat melaksanakan pembinaan harus intensif dan komunikatif, dengan mendatangi setiap guru yang mengalami kesulitan, terutama pada saat menguasai teori belajar, khususnya dalam membuat RPP berbasis pemecahan masalah

- Peneliti harus mengekspore potensi guru untuk mengembangkan kemampuannya dalam membuat RPP berbasis pemecahan masalah

\section{Hasil Pembinaan Siklus II Aktivitas Guru pada Siklus II}


Proses pembinaan pada siklus II telah memperlihatkan adanya peningkatan aktivitas guru dibanding pada siklus I, mulai dari membuat RPP untuk setiap siklus, membuat penilaian untuk setiap siklus, membuat angket respon siswa, membuat pedoman observasi aktivitas siswa, membuat daftar check, membuat format observasi aktivitas siswa, membuat format observasi pelaksanaan model pembelajaran oleh guru dan siswa, dan membuat format diskusi balikan. Aktifitas guru selama pembinaan pada siklus II dapat dilihat dari Tabel 4.3

Tabel 4.3

Aktivitas guru pada Siklus II

\begin{tabular}{|c|l|c|c|}
\hline No & \multicolumn{1}{|c|}{ Kriteria yang diamati } & Jumlah Guru & $\%$ \\
\hline 1 & $\begin{array}{l}\text { Terampil membuat RPP berbasis pemecahan } \\
\text { masalah }\end{array}$ & 14 & 77.78 \\
\hline 2 & $\begin{array}{l}\text { Terampil membuat penilaian berbasis } \\
\text { pemecahan masalah }\end{array}$ & 15 & 83.33 \\
\hline 3 & $\begin{array}{l}\text { Terampil membuat angket respon siswa } \\
\text { terhadap penggunaan PBL }\end{array}$ & 16 & 88.89 \\
\hline 4 & $\begin{array}{l}\text { Terampil membuat pedoman observasi aktivitas } \\
\text { siswa berbasis pemecahan masalah }\end{array}$ & 16 & 94.44 \\
\hline 5 & $\begin{array}{l}\text { Terampil membuat daftar check berbasis } \\
\text { pemecahan masalah }\end{array}$ & 17 & 17 \\
\hline 6 & $\begin{array}{l}\text { Terampil membuat format observasi aktivitas } \\
\text { siswa berbasis pemecahan masalah }\end{array}$ & & \\
\hline
\end{tabular}

Tabel 4.3 diatas menunjukkan bahwa guru yang melakukan aktivitas membuat RPP berbasis pemecahan masalah dengan benar, berjumlah 14 orang $(77.78 \%)$, terampil membuat penilaian berbasis pemecahan masalah sebanyak 15 orang $(83.33 \%)$, terampil membuat angket respon siswa sebanyak 16 orang $(88.89 \%)$, terampil membuat pedoman observasi aktivitas siswaberbasis pemecahan masalah sebanyak 16 orang $(88.89 \%)$, terampil membuat daftar check berbasis pemecahan masalah sebanyak 17 orang $(94.44 \%)$, dan terampil membuat format observasi aktivitas siswa berbasis pemecahan masalah sebanyak 17 orang $(94.44 \%)$. Tabel3 diatas menggambarkan bahwa kemampuanguru dalam dalam membuat RPP berbasis pemecahan masalah sudah menunjukkan peningkatan dibanding pada siklus I, yaitu skor aktivitas minimal sudah diatas $70.00 \%$ yaitu paling kecil $77.78 \%$

Evaluasi Kemampuan Guru dalam membuat RPP berbasis pemecahan masalah yang sesuai dengan tuntutan Permendikbud No 22 Tahun 2016 tentang Standar Proses pada Siklus II

Kemampuan guru dalam membuat membuat RPP berbasis pemecahan masalah yang sesuai dengan tuntutan Permendikbud No 22 Tahun 2016 tentang Standar Proses pada siklus II, dapat dilihat pada Tabel 4.4 
Tabel 4.4

Jumlah Komponen RPP Berbasis pemecahan masalah yang Dipenuhi oleh Guru (dari Total 20 Komponen RPP yang Sesuai dengan Tuntutan Permendikbud No 22 Tahun 2016) pada Siklus II

\begin{tabular}{|c|c|c|c|}
\hline No & Kode Guru & $\begin{array}{c}\text { Jumlah komponen RPP berbasis } \\
\text { pemecahan masalah yang Dipenuhi oleh } \\
\text { Guru (dari total 20 komponen RPP) }\end{array}$ & $\%$ \\
\hline 1 & AA & 16 & 80,00 \\
\hline 2 & AB & 18 & 90,00 \\
\hline 3 & AC & 13 & 65,00 \\
\hline 4 & AD & 15 & 75,00 \\
\hline 5 & AE & 18 & 90,00 \\
\hline 6 & AF & 18 & 90,00 \\
\hline 7 & AG & 17 & 85,00 \\
\hline 8 & AH & 13 & 65,00 \\
\hline 9 & AI & 17 & 85,00 \\
\hline 10 & AJ & 18 & 90,00 \\
\hline 11 & AK & 16 & 80,00 \\
\hline 12 & AL & 18 & 90,00 \\
\hline 13 & AM & 17 & 85,00 \\
\hline 14 & AN & 18 & 90,00 \\
\hline 15 & AO & 17 & 85,00 \\
\hline 16 & AP & 16 & 80,00 \\
\hline 17 & AQ & 18 & 90,00 \\
\hline 18 & AR & 16 & 80,00 \\
\hline \multicolumn{2}{|l|}{} & Rata-rata & 17 \\
\hline
\end{tabular}

Uraian 20 komponen RPP yang Sesuai dengan Tuntutan Permendikbud No 22 Tahun 2016 sebagai berikut:

\begin{tabular}{|c|c|c|c|}
\hline No & Komponen RPP & No & Komponen RPP \\
\hline 1 & $\begin{array}{l}\text { Mencantumkan identitas sekolah/nama } \\
\text { satuan pendidikan }\end{array}$ & 11 & Materi pelajaran memuat prinsip relevan dengan indikator \\
\hline 2 & Mencantumkan identitas mata pelajaran & 12 & Materi pelajaran memuat prosedur relevan dengan indicator \\
\hline 3 & Mencantumkan identitas kelas/semester & 13 & Metode pembelajaran sesuai dengan tuntutan KD/ indikator/tujuan \\
\hline 4 & $\begin{array}{l}\text { Mencantumkan materi pokok dan sub } \\
\text { materi pokok }\end{array}$ & 14 & Metode pembelajaran sesuai dengan karakteristik siswa \\
\hline 5 & $\begin{array}{l}\text { Mencantumkan alokasi waktu (termasuk } \\
\text { jumlah pertemuan) }\end{array}$ & 15 & Media pembelajaran sesuai dengan tuntutan $\mathrm{KD}$ / indikator/tujuan \\
\hline 6 & $\begin{array}{l}\text { Mencantumkan KD yang sesuai untuk } \\
\text { model berbasis pemecahan masalah }\end{array}$ & 16 & Sumber belajar sesuai dengan tuntutan KD/ indikator/tujuan \\
\hline 7 & Mencantumkan Indikator & 17 & $\begin{array}{l}\text { Langkah-langkah pembelajaran melalui tahapan pendahuluan, kegiatan inti, } \\
\text { dan penutup }\end{array}$ \\
\hline 8 & $\begin{array}{l}\text { Rumusan tujuan pembelajaran } \\
\text { berdasarkan KD/indikator }\end{array}$ & 18 & $\begin{array}{l}\text { Langkah-langkah pembelajaran memuat sintaks/ langkah-langkah model } \\
\text { berbasis pemecahan masalah (orientasi siswa kepada masalah, }\end{array}$ \\
\hline
\end{tabular}




\begin{tabular}{|c|l|c|l|}
\hline No & \multicolumn{1}{|c|}{ Komponen RPP } & No & \\
\hline & & $\begin{array}{l}\text { mengorganisasi siswa untuk belajar, membimbing penyelidikan individual } \\
\text { dan kelompok, mengembangkan dan menyajikan hasil karya, dan } \\
\text { menganalisis dan mengevaluasi proses pemecahan masalah; Sumber: } \\
\text { Arends, 2008) }\end{array}$ \\
\hline 9 & $\begin{array}{l}\text { Materi pelajaran memuat fakta relevan } \\
\text { dengan indikator }\end{array}$ & 19 & $\begin{array}{l}\text { Langkah-langkah pembelajaran mengembangkan ranah sikap, pengetahuan, } \\
\text { dan keterampilan }\end{array}$ \\
\hline 10 & $\begin{array}{l}\text { Materi pelajaran memuat konsep relevan } \\
\text { dengan indikator }\end{array}$ & 20 & Penilaian sesuai dengan tuntutan KD/ indikator/tujuan \\
\hline
\end{tabular}

Data pada Tabel 4.4 menunjukkan bahwa jumlah komponen terkecil RPP berbasis pemecahan masalah yang dipenuhi guru, dari total 20 komponen RPP yang sesuai dengan tuntutan Permendikbud No 22 Tahun 2016,pada Siklus II sebanyak 13 komponen (65.00\%) dilakukan oleh dua orang guru $(11.11 \%)$. Sedangkan jumlah komponen terbanyak yang dipenuhi guru sebanyak 18 komponen $(90.00 \%)$ dilakukan oleh tujuh orang guru (38.89\%). Rata-rata jumlah komponen yang dipenuhi guru sebanyak 17 komponen $(85.00 \%)$, dengan daya serap klasikal sebesar $88.89 \%$. Indikator daya serap klasikal sudah diatas $85,00 \%$ dengan nilai minimal 70,00, maka siklus II ini mengakhiri penelitian tindakan sekolah proses pembinaan pada guru melalui supervisi klinis.

\section{Pembahasan}

\section{Pengaruh Pembinaan Terhadap Peningkatan Aktivitas Guru dari Siklus I - Siklus II}

Kegiatan pembinaan dari siklus I sampai siklus II, menunjukkan bahwa aktivitas guru semakin aktif, serta antusias mengikuti setiap sesi pembinaan. Hampir semua guru berperan aktif mulai dari membuat RPP berbasis pemecahan masalah untuk setiap siklus, membuat penilaian berbasis pemecahan masalah untuk setiap siklus, membuat angket respon siswa, membuat pedoman observasi aktivitas siswa, membuat daftar check, dan membuat format observasi aktivitas siswa. Walaupun pada awalnya banyak yang belum terampil tetapi pada siklus II sudah menunjukkan kemajuan yang sangat pesat

\section{Pengaruh Diterapkannya Pembinaan terhadap Kemampuan dan Keterampilan Guru dalam Menguasai Teori Belajar, khususnya dalam Membuat RPP Berbasis pemecahan masalah.}

Kegiatan pembinaan dari siklus I sampai siklus II, skor guru menunjukan adanya peningkatan. Peningkatan itu menunjukkan bahwa setiap guru telah melaksanakan dan mengikuti tahap-tahap jalannya kegiatan pembinaan, serta menunjukan bahwa hampir semua guru berperan aktif mengikuti setiap sesi pembinaan yang dilakukan oleh peneliti. Selain itu, proses bimbingan dan arahan selama kegiatan pembinaan yang dilakukan sudah diupayakan efektif, efisien dan intensif. Sehingga guru tidak mengalami kesulitan dalam melaksanakan kegiatan pembinaan. Sehingga pada saat dilaksanakan pengukuran kemampuan dan keterampilan guru dalam dalam membuat RPP berbasis pemecahan masalah, pada siklus II, daya serap klasikal sudah diatas $85 \%$. Data tersebut menjadi indikator siklus II ini mengakhiri penelitian 
tindakan sekolah, kegiatan pembinaan pada guru melalui penggunaan model supervisi klinis

\section{KESIMPULAN DAN REKOMENDASI}

\section{Kesimpulan}

1) Hasil pembinaan pada siklus I, menunjukkan bahwa aktivitas guru dalam membuat RPP berbasis pemecahan masalah, membuat penilaian, membuat angket respon siswa, membuat pedoman observasi aktivitas siswa, membuat daftar check, membuat format observasi aktivitas siswa, membuat format observasi pelaksanaan model pembelajaran oleh guru dan siswa, dan membuat format diskusi balikan belum memuaskan. Kemampuan dan keahlian serta aktivitas guru dalam siklus I, perlu ditingkatkan dan harus diperbaiki pada siklus II.

2) Hasil pembinaan pada siklus II, menunjukkan bahwa aktivitas guru mulai dari membuat RPP berbasis pemecahan masalah, membuat penilaian, membuat angket respon siswa, membuat pedoman observasi aktivitas siswa, membuat daftar check, membuat format observasi aktivitas siswa, membuat format observasi pelaksanaan model pembelajaran oleh guru dan siswa, dan membuat format diskusi balikan sudah meningkat dan lenih baik dibanding siklus I. Siklus II ini mengakhiri penelitian tindakan sekolah, proses pembinaan pada guru menggunakan model supervisi klinis melalui observasirefleksi-rekomendasi, studi dokumentasi angket, FGD, dan presentasi produk RPP, dengan indikator aktivitas guru telah diatas $70.00 \%$ dan skor guru minimal 70.00 sudah diatas $85 \%$, yaitu sebesar $88.89 \%$.

3) Selama proses pembinaan mulai dari siklus I sampai siklus II, peneliti berusaha melaksanakan bimbingan serta arahan secara adil, dan menyeluruh pada setiap guru, supaya setiap guru berpartisifasi dalam mengikuti setiap sesi pembinaan, mulai dari membuat RPP berbasis pemecahan masalah untuk setiap siklus, membuat penilaian untuk setiap siklus, membuat angket respon siswa, membuat pedoman observasi aktivitas siswa, membuat daftar check, membuat format observasi aktivitas siswa,membuat format observasi pelaksanaan model pembelajaran oleh guru dan siswa, dan membuat format diskusi balikan

\section{V.REKOMENDASI}

1) Model pembinaan ini, karena telah efektif meningkatkan kemampuan dan keterampilan guru dalam mulai dari membuat RPP berbasis pemecahan masalah, oleh karena itu penerapannya tidak hanya di SMA Sumatera 40 Bandung, tetapi bisa diterapkan pada SMA lainnya baik negeri maupun swasta. Sehingga peningkatan pembinaan dapat terjadi secara menyeluruh 
2) Bagi pengawas lainnya model pembinaan ini bisa dijadikan salah satu model pembinaan yang dapat digunakan untuk meningkatkan kemampuan dan keterampilan guru dalam membuat RPP berbasis pemecahan masalah

\section{Bibliografi}

Allen et al. 1996. The power of of problem-based learning in teaching introductory science courses. New Direction for Teaching and Learning,(68), p. 43-51

Azer et al. 2013. Introducing integrated laboratory classes in a PBL curriculum: impact on student's learning and satisfaction. BMC Medical Education (13) no.71

Barret, T. 2005. Understanding Problem Based Learning. [online].Tersedia : http:// [22-03 -2007]

Barrett, T. 2005a. Understanding problem based learning. [online]. Tersedia :http://www. nuigalway. ie/celt/PBPM book

Carson, J. 2007. "A Problem with problem based learning: Teaching Thinking without Teaching Knowledge”. The Mathematics Educator, 17 (2), 7-14.

Dogru, M. 2008. The application of problem based learning on science teacher traineer on solution of environmental problems. Journal of Environmental \& Science Education, 3 (1), p. 9-18.

Duch et al. 2001. The Power of problem based learning. Virginia: Stylus Publishing, LLC

Forgaty, R. 1997. Problem Based Learning and Other Curicular Models for Multiple Intellegences Classroom. New York: IRI/Skyligt Training and Publishing, Inc

Lazear, D. 2004. Higher-order Thinking: The Multiple Intelligences Way. Chicago: Zephyr Press.

Permendikbud No. 20 Tahun 2016 tentang Standar Kompetensi Lulusan

Permendikbud No. 21 Tahun 2016 tentang Standar Isi

Permendikbud No. 22 Tahun 2016 tentang Standar Proses

Permendikbud Nomor 23 Tahun 2016 tentang Standar Penilaian

Permendikbud No. 24 Tahun 2016 tentang KI dan KD 
Permendikbud No. 143 Tahun 2014 tentang Petunjuk Teknis Jabatan Fungsional Pengawas Sekolah dan Angka Kreditnya

Permeneg PAN \& RB No.21 tahun 2010 tentang Jabatan Pengawas\&Angka Kreditnya

Salpeter. 2001. Century skill: Have Student Ready. [Online]. Tersedia: http://www.21st Centuryskill.org. [19 September 2008]

Savoi, J. M. \& Hughes, A. S. 1994. Problem based learning as classroom solution. Journal Educational Leadership, 54-57

Tan, O. S. 2003. Problem based learning Innovation: Using Problems to Power Learning in the 21st century. Singapore: Thomson Learning.

Wood, D. 2005. Problem based learning especiallyin the contex to flarge classes. [Online]. Tersedia: [12 Maret 2008]. 